Article

\title{
Preparation of Sterically Demanding 2,2-Disubstituted-2-Hydroxy Acids by Enzymatic Hydrolysis
}

\author{
Andrea Pinto ${ }^{1, *}$, Immacolata Serra ${ }^{1}$, Diego Romano ${ }^{1}$, Martina Letizia Contente ${ }^{1}$, \\ Francesco Molinari ${ }^{1}$, Fabio Rancati ${ }^{2}$ D, Roberta Mazzucato ${ }^{2}$ and Laura Carzaniga $2, *$ (D) \\ 1 Department of Food, Environmental and Nutritional Science (DeFENS), University of Milan, \\ 20133 Milan, Italy; Immacolata.serra@unimi.it (I.S.); diego.romano@unimi.it (D.R.); \\ martina.contente@nottingham.ac.uk (M.L.C.); francesco.molinari@unimi.it (F.M.) \\ 2 Chemistry Research and Drug Design Department, Corporate Preclinical R\&D, Chiesi Farmaceutici S.p.A., \\ 43122 Parma, Italy; F.Rancati@chiesi.com (F.R.); R.Mazzucato@chiesi.com (R.M.) \\ * Correspondence: andrea.pinto@unimi.it (A.P.); L.Carzaniga@chiesi.com (L.C.); \\ Tel.: +39-02503-16814 (A.P.); +39-0521-279652 (L.C.)
}

Received: 18 December 2018; Accepted: 19 January 2019; Published: 24 January 2019

\begin{abstract}
Preparation of optically-pure derivatives of 2-hydroxy-2-(3-hydroxyphenyl)-2-phenylacetic acid of general structure 2 was accomplished by enzymatic hydrolysis of the correspondent esters. A screening with commercial hydrolases using the methyl ester of 2-hydroxy-2-(3-hydroxyphenyl)-2-phenylacetic acid (1a) showed that crude pig liver esterase (PLE) was the only preparation with catalytic activity. Low enantioselectivity was observed with substrates $1 \mathrm{a}-\mathrm{d}$, whereas PLE-catalysed hydrolysis of 1e proceeded with good enantioselectivity $(E=28)$, after optimization. Enhancement of the enantioselectivity was obtained by chemical re-esterification of enantiomerically enriched $2 \mathrm{e}$, followed by sequential enzymatic hydrolysis with PLE. The preparation of optically-pure $(S)$-2e was validated on multi-milligram scale.
\end{abstract}

Keywords: esterase; stereoselective; ester hydrolysis; antimuscarinic agents; pig liver esterase (PLE)

\section{Introduction}

Enzymatic hydrolysis of chiral esters using carboxylesterases is an established method for obtaining kinetic and dynamic resolution [1-5]. A number of stereoselective carboxylesterases is nowadays available, and troublesome application such as the hydrolysis of spatially bulky substrates can be solved by screening and protein engineering [6]. Esters of carboxylic acids with sterically-demanding $\alpha$-substitutions are not easily hydrolysed by most of the lipases, and protein engineering for making natural enzymes able to accept these substrates is still limited to relatively bulky carboxylic acids [7]. Enzymatic hydrolysis of carboxylic acid esters having an $\alpha$-quaternary or $\alpha$-tertiary centre is still a difficult task [8]; in contrast to the broad spectrum of esters with bulky alcohol moieties accepted as substrates $[9,10]$. Activation by electron-withdrawing (EW) hetero-atoms (e.g., $\mathrm{O}$ and $\mathrm{N}$ ) or by EW-functional groups (e.g., $-\mathrm{NO}_{2},-\mathrm{CN},-\mathrm{CF}_{3}$ ) is often required to observe enzymatic hydrolytic activity [11-13]. $\alpha-, \alpha$-Disubstituted malonate diesters are among the few $\alpha-, \alpha-, \alpha$-trisubstituted carboxylic esters accepted by carboxylesterases; in particular, pig liver esterase (PLE) is particularly suited for catalyzing the enantioselective monohydrolysis of differently substituted malonate diesters [14], including ester derivatives, such as dimethyl 3,3-dimethyl-2-methylenecyclohexane-1,1- dicarboxylate, a chiral building block used for the enantioselective total synthesis of ent-kauranoids [15]. 
In this work, we have studied the enzymatic hydrolysis of esters 1 , derivatives of sterically demanding 2,2-diaryl-2-hydroxy acids 2 (Figure 1); these molecules attract great attention for pharmaceutical applications as they can be useful chiral building blocks for the synthesis of compounds exerting muscarinic M3 receptor antagonist activity [16,17]. Antimuscarinic agents have a variety of applications but one of the most well established is their use as inhaled bronchodilators for the treatment of obstructive airway diseases such as asthma and chronic obstructive pulmonary disease (COPD) [18]. The enzymatic hydrolysis of ester 1 has been therefore investigated as a possibly suitable, affordable and sustainable method alternative to classical liquid (LC)/supercritical fluid chromatography (SFC) chiral separation of racemic mixtures or diastereomeric salt crystallization, to obtain the desired active (S)-enantiomer 2.

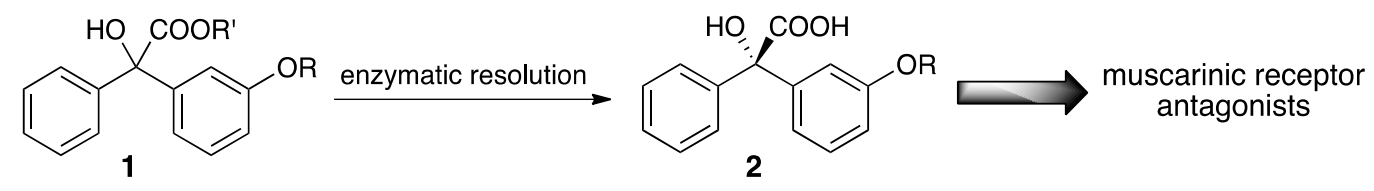

Figure 1. Kinetic resolution of esters of 2,2-diaryl-2-hydroxy acids; optically pure acids are building blocks for the synthesis of muscarinic receptor antagonists.

\section{Results}

\subsection{Screening of Biocatalysts and Substrates}

The synthesis of esters 1a-e, used in this work, was realized as described in Scheme 1.

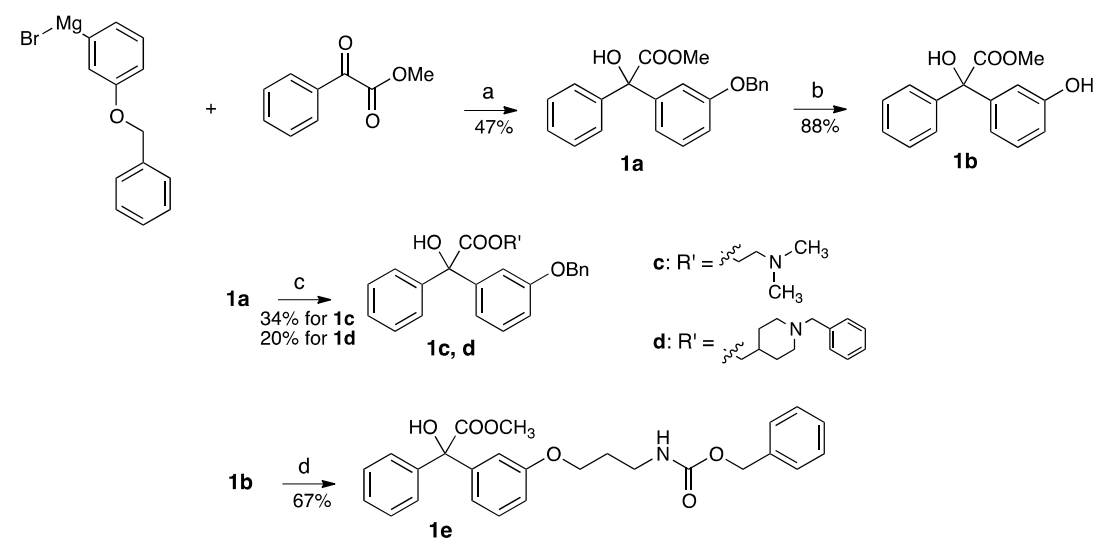

Scheme 1. Synthesis of esters 1a-e. Reaction conditions: a: THF, RT, 16 h; b: dihydrotoluene, $10 \% \mathrm{Pd} / \mathrm{C}$, $\mathrm{EtOH}$, reflux, eight hours; c: (i) $\mathrm{LiOH}, \mathrm{THF} /$ water, RT, 2 h; (ii) CDI, 2-(dimethylamino)ethanol, $\mathrm{CH}_{2} \mathrm{Cl}_{2}$, $60^{\circ} \mathrm{C}, 4 \mathrm{~h}$; d: N-(benzyloxycarbonyl)-3-amino-1-propyl methanesulfonate, $\mathrm{CsCO}_{3}, \mathrm{DMF}, \mathrm{RT}, 16 \mathrm{~h}$.

Hydrolysis of $1 \mathrm{a}-\mathrm{b}$ was firstly investigated using 20 commercial hydrolases and 15 enzymatic preparations from our laboratory [19-24]; only commercial PLE gave hydrolysis of 1a,b (Scheme 2) with conversions ranging between 50 and $100 \%$ after $24 \mathrm{~h}$ (Table 1).

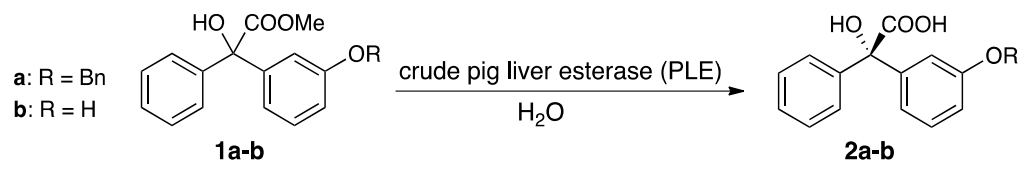

Scheme 2. Enzymatic hydrolysis of esters 1a-b with pig liver esterase (PLE). 
Table 1. Hydrolysis of $1 \mathrm{a}-\mathrm{b}$ with pig liver esterase (PLE); Conditions: $[\mathrm{S}]=2.5 \mathrm{mM}$, [PLE] $=7.5 \mathrm{mg} / \mathrm{mL}$ in $100 \mathrm{mM}$ phosphate buffer at $\mathrm{pH}=7.0$ and DMSO $(5 \%), 30^{\circ} \mathrm{C}$.

\begin{tabular}{ccccccc}
\hline Entry & Substrate & $\begin{array}{c}\text { Conv. } \\
(\mathbf{\%})\end{array}$ & ee $_{(\boldsymbol{R}) \text {-ester }}(\mathbf{\%})$ & ee $_{(\boldsymbol{S}) \text {-acid }} \mathbf{( \% )}$ & E & Time (h) \\
\hline 1 & $1 \mathrm{a}$ & 52 & 67 & 63 & 8 & 5 \\
2 & $1 \mathrm{a}$ & $>97$ & $<5$ & $<5$ & - & 24 \\
3 & $1 \mathrm{~b}$ & 50 & 67 & 67 & 10 & 5 \\
4 & $1 \mathrm{~b}$ & $>97$ & $<5$ & $<5$ & - & 24 \\
\hline
\end{tabular}

The reactions occurred with excellent rates, but low enantioselectivity, furnishing the $S$-acid with enantiomeric ratio (E) ranging between 8 and 10. Absolute configurations were assigned by comparison with enantiomerically pure sample previously synthesized [16]. Different (bulkier) alcohol moieties were introduced with the aim of increasing the enantioselectivity, therefore esters $1 \mathrm{c}, \mathrm{d}$ were synthesized as shown before and used as substrates for the enzymatic hydrolysis with commercial PLE, but enantioselectivity remained quite low ( $\mathrm{E}<8$ in both the cases).

As a strategy for improving enantioselectivity, we synthesized 1e, where a benzyloxy propylcarbamate was introduced as meta-substituent for boosting the structural diversity of the two aromatic groups (Scheme 3).
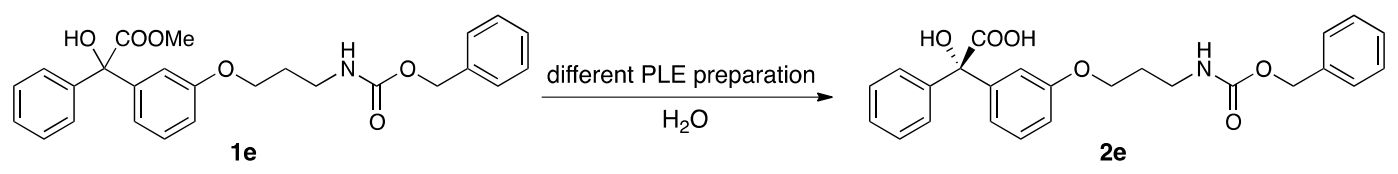

Scheme 3. Enzymatic hydrolysis of ester 1ewith pig liver esterase (PLE).

In fact, the kinetic resolution of 1e occurred with higher enantioselectivity ( $E=21$, entry 1, Table 2) than what observed with 1a-d. Commercial PLE preparation is extracted from animal tissues and composed by 6 different isoenzymes, each one potentially leading to different stereoselectivity [14,25]; therefore, we also tested the six isoforms as single recombinant enzymes (commercially available and named ECS-PLE 01-06) for the hydrolysis of 1e (Table 2, entries 2-7).

Table 2. Hydrolysis of 1e with PLE; conditions: [S] = $2.5 \mathrm{mM}$, [PLE] $7.5 \mathrm{mg} / \mathrm{mL}$ in $100 \mathrm{mM}$ phosphate buffer at $\mathrm{pH}=7.0$ and $\mathrm{DMSO}(5 \%), 30^{\circ} \mathrm{C}$.

\begin{tabular}{|c|c|c|c|c|c|c|}
\hline Entry & Substrate & Conv. (\%) & ee $(R)$-ester $(\%)$ & ee $(S)$-acid $(\%)$ & $\mathrm{E}$ & Time (h) \\
\hline 1 & Crude PLEs & 30 & 37 & 87 & 21 & 5 \\
\hline 2 & ECS-PLE01 & $<5$ & - & - & - & 24 \\
\hline 3 & ECS-PLE02 & $<5$ & - & - & - & 24 \\
\hline 4 & ECS-PLE03 & 19 & 8 & 30 & $<5$ & 24 \\
\hline 5 & ECS-PLE04 & 8 & - & n.d. & - & 24 \\
\hline 6 & ECS-PLE05 & $<5$ & - & - & - & 24 \\
\hline 7 & ECS-PLE06 & 37 & 51 & 87 & 24 & 24 \\
\hline
\end{tabular}

The highest enantioselectivity was observed with the recombinant isoform ECS-PLE06 (entry 7, Table 3), comparable with the one obtained with crude PLE, which, in turn, showed higher specific activity.

\subsection{Optimization}

Crude PLE was therefore used for further optimization, carried out using an experimental design (Multisimplex v2.0 (Multisimplex AB, Karlskrona, Sweden), previously used for optimizing the conditions of different biotransformations [26]. The control variables were substrate and enzyme concentration, $\mathrm{pH}, \mathrm{co}-\mathrm{solvent}$ (DMSO) concentration, and temperature. Productivity at $24 \mathrm{~h}$ and 
enantioselectivity were chosen as response parameters. Under optimized conditions ([S] $=3.5 \mathrm{mg} / \mathrm{mL}$ $(8 \mathrm{mM}) ;[\mathrm{Enz}]=5.0 \mathrm{mg} / \mathrm{mL}$; solvent $0.1 \mathrm{M}$ phosphate buffer $/ \mathrm{DMSO} 8 \%, \mathrm{pH}=7.0$ at $\left.25^{\circ} \mathrm{C}\right)$, where the ratio between substrate and enzyme was reduced, the highest enantioselectivity $(\mathrm{E}=28)$ was obtained, but reaction rate slowed down. Under these conditions, enzymatic hydrolysis gave $2 \mathrm{e}$ with an ee of $90 \%$ after $24 \mathrm{~h}$, in correspondence of $30 \%$ conversion.

As previously reported, the addition of co-solvents, which alter the solubility of the substrate, may affect the enantioselectivity and the reaction rate of reactions catalyzed by crude PLE [14,27]. Consequently, we investigated the activity and the enantioselectivity on the hydrolysis of 1e with crude PLE carried out under optimized conditions in the presence of the solvents listed in Table 3.

Table 3. Hydrolysis of 1e with PLE in the presence of different co-solvents. Conditions: [S] $=8 \mathrm{mM}$, [PLE] $=5.0 \mathrm{mg} / \mathrm{mL}$ in $100 \mathrm{mM}$ phosphate buffer at $\mathrm{pH}=7.0$ and co-solvents (amounts as indicated in Table), $25^{\circ} \mathrm{C}$. Results after $24 \mathrm{~h}$.

\begin{tabular}{|c|c|c|c|c|c|}
\hline Entry & Co-solvent $(\% v / v)$ & Conv. (\%) & ee $(R)$-ester $(\%)$ & ee $(\mathrm{S})$-acid $(\%)$ & E \\
\hline 1 & none & 30 & 23 & 90 & 23 \\
\hline 2 & $\mathrm{EtOH}(8)$ & $<5$ & - & - & - \\
\hline 3 & iPrOH (8) & $<5$ & - & - & - \\
\hline 4 & DMSO (8) & 30 & 39 & 90 & 28 \\
\hline 5 & THF (8) & 10 & 9 & 79 & 10 \\
\hline 6 & acetone (8) & $<5$ & - & - & - \\
\hline 7 & $\mathrm{Et}_{2} \mathrm{O}(30)$ & $<5$ & - & - & - \\
\hline 8 & toluene (30) & $<5$ & - & - & - \\
\hline 9 & $n$-heptane (30) & 22 & 25 & 90 & 21 \\
\hline 10 & isooctane (30) & 25 & 30 & 88 & 21 \\
\hline
\end{tabular}

Protic water-soluble co-solvents (EtOH and $i \mathrm{PrOH}$, entries 2 and 3, Table 3) suppressed enzymatic activity, whereas, DMSO (firstly chosen as co-solvent) was the only polar co-solvent with beneficial effects (entry 4, Table 3). Detected activity and enantioselectivity in the presence of highly hydrophobic solvents ( $n$-heptane and isooctane, entries 9 and 10, Table 3) were lower than the ones obtained in water containing $8 \%$ DMSO. Reactions performed in the presence of different concentrations of hydrophobic solvents $(10,30,50 \% v / v)$ did not show any significant differences.

Another way to influence the overall reactivity of organic substrates in aqueous enzymatic reactions involves the use of cyclodextrins (CDX) [28]. CDX can modify the solubility of organic compounds in water, while establishing diastereoisomeric interactions with chiral substrates; for these reasons, different CDX were tested as additive in the enzymatic hydrolysis of 1e (Table 4).

Table 4. Hydrolysis of $1 \mathrm{e}$ with PLE in the presence of $\beta$-cyclodextrins; conditions: [S] $=8 \mathrm{mM}$, $[P L E]=5.0 \mathrm{mg} / \mathrm{mL},[C D X] 10 \mathrm{mM}$ in $100 \mathrm{mM}$ phosphate buffer and DMSO (8\%) at $\mathrm{pH}=7.0,25^{\circ} \mathrm{C}$. Results after $24 \mathrm{~h}$.

\begin{tabular}{cccccc}
\hline Entry & $\boldsymbol{\beta}$-Cyclodextrin & Conv. (\%) & ee $_{\text {ester }} \mathbf{( \% )}$ & ee $_{\text {acid }} \mathbf{( \% )}$ & E \\
\hline 1 & underivatized & 45 & 70 & 86 & 28 \\
2 & triacetyl & 40 & 59 & 88 & 28 \\
3 & methyl & 33 & 44 & 88 & 24 \\
4 & trimethylammonium & 25 & 31 & 91 & 28 \\
\hline
\end{tabular}

Cyclodextrins generally improved the reaction rates, with $\beta$-CDX showing the highest acceleration (entry 1, Table 4). The screening shown in Table 5 was carried out using a slight excess of CDX over the substrate, so we decided to explore the effect of different stoichiometric ratios between $\beta$-CDX and substrate (Table 5), observing that no significant improvements were obtained above 1.25 ratio $\beta$-CDX/substrate. 
Table 5. Hydrolysis of $1 \mathrm{e}$ with PLE in the presence of different amounts of $\beta$-cyclodextrin $(\beta$-CDX); conditions: $[\mathrm{S}]=8 \mathrm{mM}[\mathrm{PLE}]=5.0 \mathrm{mg} / \mathrm{mL}$, different amounts of $\beta$-CDX in $100 \mathrm{mM}$ phosphate buffer and DMSO $(8 \%)$ at $\mathrm{pH}=7.0,25^{\circ} \mathrm{C}$. Results after $24 \mathrm{~h}$.

\begin{tabular}{cccccc}
\hline Entry & Ratio $[\boldsymbol{\beta}-\mathrm{CDX}] /[\mathrm{S}]$ & Conv. $(\mathbf{\%})$ & ee $_{\text {ester }}(\mathbf{\%})$ & ee $_{\text {acid }}(\mathbf{\%})$ & $\mathbf{E}$ \\
\hline 1 & 1 & 41 & 60 & 86 & 24 \\
2 & 1.25 & 45 & 70 & 86 & 28 \\
3 & 1.5 & 45 & 70 & 86 & 28 \\
4 & 2 & 48 & 78 & 84 & 28 \\
\hline
\end{tabular}

\subsection{Preparative Biotransformation}

A preparative biotransformation was thus performed starting from $150 \mathrm{mg}$ of 1e (Figure 2) using the best reaction conditions (entry 2, Table 5).

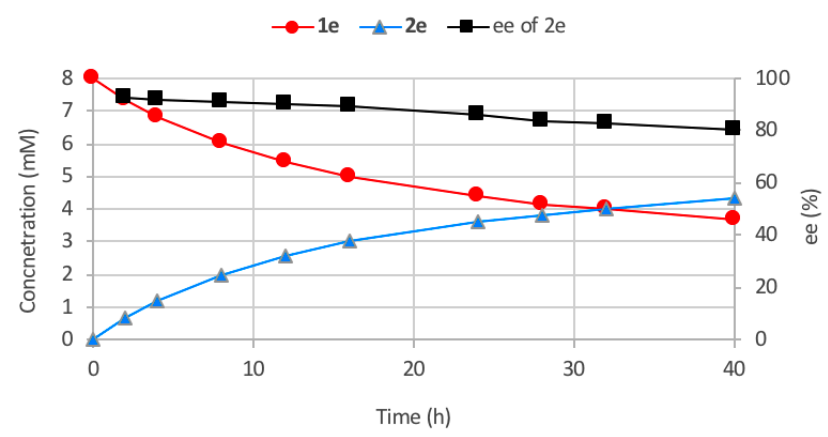

Figure 2. Preparative kinetic resolution of 1e. Conditions. [S] $=8 \mathrm{mM},[\mathrm{PLE}]=5.0 \mathrm{mg} / \mathrm{mL}$, $[\beta-C D X]=10 \mathrm{mM}$ in phosphate buffer $(100 \mathrm{mM})$ and DMSO $(8 \%)$ at $\mathrm{pH}=7.0,25^{\circ} \mathrm{C}$.

The reaction was stopped in correspondence of 54\% conversion (after $40 \mathrm{~h}$ ), allowing for the recovery and purification of $2 \mathrm{e}(67 \mathrm{mg})$ with an ee of $80 \%$. This batch of optically-enriched $2 \mathrm{e}$ was chemically methylated to give optically enriched 1e, which was subsequently hydrolysed with PLE, furnishing $50 \mathrm{mg}$ of optically pure $(S)-2 \mathrm{e}$. The overall results of this sequential kinetic resolution are given in Scheme 4.
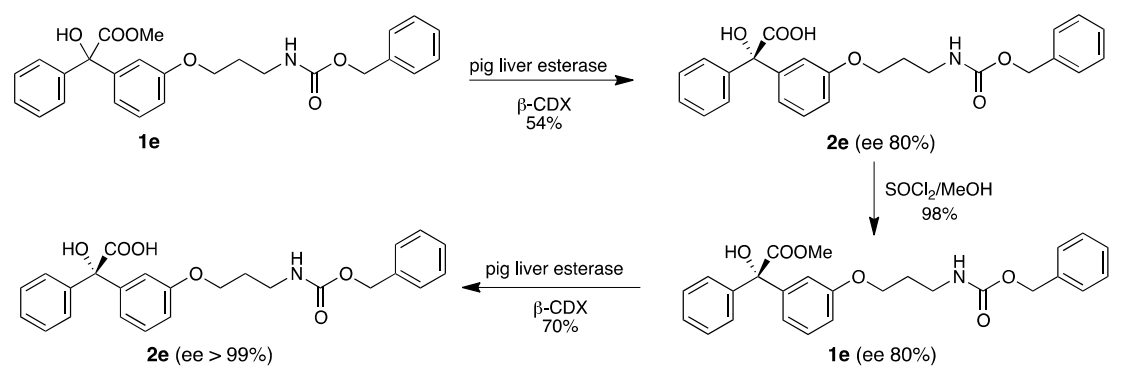

Scheme 4. Preparation of optically pure 2e after sequential enzymatic hydrolysis of 1e with PLE.

\section{Discussion}

Sterically demanding 2,2-diaryl-2-hydroxy carboxylic acids are valuable chiral building blocks for the synthesis of antimuscarinic agents [9]. Two major problems were encountered in the enzymatic kinetic resolution of these bulky substrates. Firstly, esters having $\alpha$-quaternary or $\alpha$-tertiary center show severe steric hindrance that hampers the approach to the active site; in fact, among the different enzymes tested, PLE was the only enzyme active on these substrates. Besides, esters of 2-hydroxy-2-(3-hydroxyphenyl)-2-phenylacetate (the ones considered here as key precursors for antimuscarinic agents preparation) display poor stereo-discrimination due to the presence of two aromatic groups, directly bound to the stereocenter, which differ only for the presence of 
a meta-substituent on one of the two aromatic rings. Derivative 1e, which bears a benzyloxy propylcarbamate substituent in meta-position, gives sufficient stereo-differentiation for achieving moderate-to-good enantioselectivity $(\mathrm{E}=28)$. Moreover, the biotransformation was optimized by choosing suited co-solvents (DMSO) and additives ( $\beta$-CDX).

The preparative significance of this method was established by the expedient preparation of optically pure (S)-2e on multi-milligram scale, using a sequential kinetic resolution approach.

\section{Materials and Methods}

All chemicals were from Sigma-Aldrich (Milano, Italy) and/or VWR International (Milano, Italy) and used without further purification unless otherwise stated. Pig liver esterase was purchased from Sigma-Aldrich (Milano, Italy). PLE isoforms were from Enzymicals (Greifswald, Germany). $\beta$-Cyclodextrins were provided by Wacker-Chemie GmbH (Munchen, Germany). Anhydrous solvents were purchased from Aldrich and used as received. "Brine" refers to a saturated aqueous solution of $\mathrm{NaCl}$. Unless otherwise specified, solutions of common inorganic salts used in workups are aqueous solutions. Optically pure/enriched compounds, used as HPLC standards, were synthesised as previously described [17].

\subsection{Analyticals}

HPLC analyses were performed with a Jasco PU-980 pump equipped with a UV-VIS detector Jasco UV-975 (Easton, MD, USA). The NMR of ${ }^{1} \mathrm{H}$ and ${ }^{13} \mathrm{C}$ spectra were recorded in DMSO using Bruker $600 \mathrm{MHz}$ or $400 \mathrm{MHz}$ spectrometer (Karlsruhe, Germany), equipped with a self-shielded z-gradient coil $5 \mathrm{~mm}{ }^{1} \mathrm{H} /{ }^{\mathrm{n}} \mathrm{X}$ broad band probehead for reverse detection, deuterium digital lock channel unit, quadrature digital detection unit with transmitter offset frequency shift. Chemical shifts are reported as $\delta$ downfield in parts per million (ppm) and referenced to tetramethylsilane (TMS) as the internal standard in the ${ }^{1} \mathrm{H}$ measurements. Coupling constants (J values) are given in hertz $(\mathrm{Hz})$ and multiplicities are reported using the following abbreviation $(\mathrm{s}=\operatorname{singlet}, \mathrm{d}=$ doublet, $\mathrm{t}=$ triplet, $\mathrm{q}=$ quartet, $\mathrm{m}=$ multiplet, $\mathrm{br}=$ broad, $\mathrm{nd}=$ not determined). The pulse programs were taken from the Varian and Bruker software libraries. The HRMS spectra were recorded on an Agilent instrument (Santa Clara, CA, USA) using the Time-of-Flight Mass Spectrometry (TOF MS) technique. Specific rotation of compounds was measured with a Polarimeter Perkin Elmer (model 241 or 341, Waltham, USA) at sodium D-line ( $589 \mathrm{~nm}), 25^{\circ} \mathrm{C}, 1 \mathrm{dm}$ path length. Reactions were monitored by TLC using $0.25 \mathrm{~mm}$ Merck silica gel plates (60 F254, Darmstadt, Germany). For chiral analysis the samples were analysed using a chiral column for the separation of the enantiomers. HPLC analyses were carried out on a Kromasil 5-Amycoat column $4.6 \times 250 \mathrm{~mm}$ (CPS Analitica, Milan, Italy), $5 \mu \mathrm{m}$; mobile phase: n-hexane:isopropanol:TFA 8:2:0.1\%, flow rate $1 \mathrm{~mL} / \mathrm{min}, \lambda=220 \mathrm{~nm}$. Optically pure/enriched compounds were chemically synthesised as chiral HPLC standards. Column chromatography was performed on Merck silica gel 60 (0.063-0.2 mm).

\subsection{Procedure for the Synthesis of methyl 2-(4-(benzyloxy)phenyl)-2-hydroxy-2-phenylacetate (1a)}

To a solution of methyl 2-oxo-2-phenylacetate (12.83 mL, $91 \mathrm{mmol})$ in THF (Volume: $350 \mathrm{~mL}$ ), (4-(benzyloxy)phenyl)magnesium bromide $\left(100 \mathrm{~mL}, 100 \mathrm{mmol}\right.$ ) was added dropwise at $0{ }^{\circ} \mathrm{C}$ over $30 \mathrm{~min}$ and stirred overnight at RT. Reaction was partitioned between $\mathrm{AcOEt}$ and saturated $\mathrm{NaCl}$, organic phase dried over $\mathrm{Na}_{2} \mathrm{SO}_{4}$ and evaporated. The oily residue was crystalized in $\mathrm{Et}_{2} \mathrm{O}$ to afford methyl 2-(4-(benzyloxy)phenyl)-2-hydroxy-2-phenylacetate ( $15 \mathrm{~g}, 43.1 \mathrm{mmol}, 47.4 \%$ yield) as white solid. ${ }^{1} \mathrm{H}$ NMR $(600 \mathrm{MHz}$, DMSO-d6; $\delta$ ppm 7.24-7.44 (m, $11 \mathrm{H}) 6.94-6.98(\mathrm{~m}, 2 \mathrm{H}) 6.91(\mathrm{dt}, \mathrm{J}=8.08$, $1.15 \mathrm{~Hz}, 1 \mathrm{H}) 6.67(\mathrm{~s}, 1 \mathrm{H}) 5.06(\mathrm{~s}, 2 \mathrm{H}) 3.71(\mathrm{~s}, 3 \mathrm{H}) ;{ }^{13} \mathrm{C}$ NMR $(151 \mathrm{MHz}$, DMSO-d6) $\delta$ ppm 173.97 (s, 1 C) 158.36 (s, 1 C) 145.33 (s, 1 C) 143.63 (s, 1 C) 137.45 (s, 1 C) 129.35 (s, 1 C) 128.88 (s, 1 C) 128.28 (s, 1 C) 128.25 (s, 1 C) 128.15 (s, 1 C) 127.92 (s, 1 C) 127.40 (s, 1 C) 120.06 (s, 1 C) 114.50 (s, 1 C) 113.84 (s, 1 C) 81.05 (s, 1 C) $69.70(\mathrm{~s}, 1 \mathrm{C}) 52.96(\mathrm{~s}, 1 \mathrm{C})$. HRMS (ESI-TOF): Exact mass calculated for $\mathrm{C}_{22} \mathrm{H}_{20} \mathrm{O}_{4}$ 
$[\mathrm{M}-\mathrm{H}]^{-}=347.1289$, Found: $\left[\mathrm{M}+\mathrm{NH}_{4}\right]^{+}=366.1698 .{ }^{1} \mathrm{H}$ NMR and ${ }^{13} \mathrm{C}$ NMR spectra of 1a are reported in Supplementary Materials (Figures S2 and S3, respectively).

\subsection{Procedure for the Synthesis of methyl 2-hydroxy-2-(3-hydroxyphenyl)-2-phenylacetate (1b)}

Methyl 2-(3-(benzyloxy)phenyl)-2-hydroxy-2-phenylacetate (1a) (200 mg, $0.574 \mathrm{mmol}$ ), 1-methylcyclohexa-1,4-diene (129 $\mu \mathrm{l}, 1.148 \mathrm{mmol})$ and $\mathrm{Pd} / \mathrm{C} 10 \%$ wet $(60 \mathrm{mg}, 0.028 \mathrm{mmol})$ were refluxed in EtOH $(2870 \mu \mathrm{l})$ in a closed vessel at $80{ }^{\circ} \mathrm{C}$ for $8 \mathrm{~h}$, then the mixture filtered on PTFE membrane and evaporated under reduced pressure. The resulting oil was recrystallized in a mixture of cyclohexane/iPr $2 \mathrm{O}$ to give methyl 2-hydroxy-2-(3-hydroxyphenyl)-2-phenylacetate (130 mg, $0.503 \mathrm{mmol}, 88 \%$ yield) as a white powder. ${ }^{1} \mathrm{H}$ NMR $(600 \mathrm{MHz}$, DMSO-d6) $\delta \mathrm{ppm} 9.35$ (s, $1 \mathrm{H}) 7.32$ (d, $\mathrm{J}=4.29 \mathrm{~Hz}, 4 \mathrm{H}) 7.25-7.30(\mathrm{~m}, 1 \mathrm{H}) 7.11(\mathrm{t}, \mathrm{J}=7.87 \mathrm{~Hz}, 1 \mathrm{H}) 6.74-6.77(\mathrm{~m}, 1 \mathrm{H}) 6.73(\mathrm{dd}, \mathrm{J}=1.67,0.95 \mathrm{~Hz}$, $1 \mathrm{H}) 6.67(\mathrm{ddd}, \mathrm{J}=8.02,2.41,0.89 \mathrm{~Hz}, 1 \mathrm{H}) 6.55(\mathrm{~s}, 1 \mathrm{H}) 3.71(\mathrm{~s}, 3 \mathrm{H}) ;{ }^{13} \mathrm{C}$ NMR $((151 \mathrm{MHz}$, DMSO-d6) $\delta$ ppm $174.14(\mathrm{~s}, 1 \mathrm{C}) 157.33(\mathrm{~s}, 1 \mathrm{C}) 145.20(\mathrm{~s}, 1 \mathrm{C}) 143.82(\mathrm{~s}, 1 \mathrm{C}) 129.17(\mathrm{~s}, 1 \mathrm{C}) 128.15(\mathrm{~s}, 1 \mathrm{C}) 127.81(\mathrm{~s}, 1 \mathrm{C})$ 127.50 (s, 1 C) 118.08 (s, 1 C) 114.89 (s, 1 C) 114.70 (s, 1 C) 81.10 (s, 1 C) 52.87 (s, 1 C); HRMS (ESI-TOF): Exact mass calculated for $\mathrm{C}_{15} \mathrm{H}_{14} \mathrm{O}_{4}[\mathrm{M}-\mathrm{H}]^{-}=257.0819$, Found: $[\mathrm{M}+\mathrm{Na}]^{+}=281.0783 .{ }^{1} \mathrm{H}$ NMR and ${ }^{13} \mathrm{C}$ NMR spectra of $1 \mathrm{~b}$ are reported in Supplementary Materials (Figures S4 and S5, respectively).

\subsection{Procedure for the Synthesis of 2-(dimethylamino)ethyl}

2-(3-(benzyloxy)phenyl)-2-hydroxy-2-phenylacetate (1c)

Methyl 2-(3-(benzyloxy)phenyl)-2-hydroxy-2-phenylacetate (1a) (5 g, $14.35 \mathrm{mmol})$ and $\mathrm{LiOH}$ $(1.031 \mathrm{~g}, 43.1 \mathrm{mmol})$ were dissolved in THF (Volume: $15 \mathrm{~mL}$ )/Water (Volume: $15.00 \mathrm{~mL}$ ) and stirred for $2 \mathrm{~h}$ at RT. Reaction was quenched by the addition on $1 \mathrm{M} \mathrm{HCl}$ and extracted with AcOEt, the organic phase was washed with aqueous $\mathrm{NaCl}$ and dried over $\mathrm{Na}_{2} \mathrm{SO}_{4}$ before being evaporated under reduced pressure. The desired product 2-(3-(benzyloxy)phenyl)-2-hydroxy-2-phenylacetic acid (2a) (5.1 g, $15.25 \mathrm{mmol}, 106 \%$ yield) was obtained as a yellowish foam, not isolated and used as such for the following step. 2-(3-(Benzyloxy)phenyl)-2-hydroxy-2-phenylacetic acid (2a) (2.5 g, $7.48 \mathrm{mmol}$ ) and CDI $(2.425 \mathrm{~g}, 14.95 \mathrm{mmol}$ ) were reacted for $5 \mathrm{~min}$ in DCM (Volume: $8 \mathrm{~mL}$ ) prior the addition of 2-(dimethylamino)ethanol $(2.257 \mathrm{~mL}, 22.43 \mathrm{mmol})$. Reaction was stirred for $4 \mathrm{~h}$ at $60^{\circ} \mathrm{C}$, then partitioned between AcOEt and sat $\mathrm{NaHCO}_{3}$ aq, washed twice with water, dried over $\mathrm{Na}_{2} \mathrm{SO}_{4}$ and evaporated under reduced pressure. The crude was chromatographed on silica gel by gradient elution from $100 \%$ AcOEt to AcOEt/MeOH (7N NH3) 90/10 in $12 \mathrm{CV}$ to give 2-(dimethylamino)ethyl 2-(3-(benzyloxy)phenyl)-2-hydroxy-2-phenylacetate (1c) $(1.02 \mathrm{~g}, 2.52 \mathrm{mmol}, 33.6 \%$ yield) as a yellowish oil. ${ }^{1} \mathrm{H}$ NMR (600 MHz, DMSO-d6) $\delta$ ppm 7.23-7.44 (m, $\left.12 \mathrm{H}\right) 6.98-7.01(\mathrm{~m}, 1 \mathrm{H}) 6.92-6.96(\mathrm{~m}, 2 \mathrm{H})$ $6.58(\mathrm{~s}, 1 \mathrm{H}) 5.05(\mathrm{~s}, 2 \mathrm{H}) 4.23(\mathrm{t}, \mathrm{J}=5.57 \mathrm{~Hz}, 2 \mathrm{H}) 2.12(\mathrm{~s}, 6 \mathrm{H}) ;{ }^{13} \mathrm{C}$ NMR $(151 \mathrm{MHz}, \mathrm{DMSO}-\mathrm{d} 6) \delta$ ppm 173.34 (s, 1 C) 158.33 (s, 1 C) 145.30 (s, 1 C) 143.63 (s, 1 C) 137.47 (s, 1 C) 129.25 (s, 1 C) 128.87 (s, 1 C) $127.88(\mathrm{~s}, 1 \mathrm{C}) 127.54(\mathrm{~s}, 1 \mathrm{C}) 127.43(\mathrm{~s}, 1 \mathrm{C}) 120.21$ (s, 1 C) 114.69 (s, 1 C) $113.80(\mathrm{~s}, 1 \mathrm{C}) 81.06$ (s, 1 C) 69.69 (s, 1 C) 63.47 (s, 1 C) 57.42 (s, 1 C) 45.54 (s, 1 C). HRMS (ESI-TOF): Exact mass calculated for $\mathrm{C}_{25} \mathrm{H}_{27} \mathrm{O}_{4} \mathrm{~N}[\mathrm{M}]^{+}=405.1940$, Found $[\mathrm{M}-\mathrm{H}]^{+}=406.2011{ }^{1} \mathrm{H}$ NMR and ${ }^{13} \mathrm{C}$ NMR spectra of $1 \mathrm{c}$ are reported in Supplementary Materials (Figures S6 and S7, respectively). ${ }^{1} \mathrm{H}$ NMR and ${ }^{13} \mathrm{C}$ NMR spectra of 1c are reported in Supplementary Materials (Figures S6 and S7, respectively).

\subsection{Procedure for the Synthesis of (1-benzylpiperidin-4-yl)methyl}

2-(3-(benzyloxy) phenyl)-2-hydroxy-2-phenylacetate (1d)

2-(3-(benzyloxy)phenyl)-2-hydroxy-2-phenylacetic acid (2a) $(2.5 \mathrm{~g}, 7.48 \mathrm{mmol}$ ) and CDI $(2.425 \mathrm{~g}, 14.95 \mathrm{mmol}$ ) were reacted for $5 \mathrm{~min}$ in DCM (Volume: $15 \mathrm{~mL}$ ) prior the addition of (1-benzylpiperidin-4-yl)methanol $(2.3 \mathrm{~g}, 11.20 \mathrm{mmol})$. Reaction was stirred for $3 \mathrm{~h}$ at $60{ }^{\circ} \mathrm{C}$, then DMF was added and the mixture was stirred at $80^{\circ} \mathrm{C}$ for $4 \mathrm{~h}$. The mixture was partitioned between AcOEt and an aqueous solution of $\mathrm{NaHCO}_{3}$, washed twice with water, dried over $\mathrm{Na}_{2} \mathrm{SO}_{4}$ and evaporated under reduced pressure. The crude was chromatographed first on silica gel (gradient elution from $100 \% \mathrm{AcOEt}$ to $\mathrm{AcOEt} / \mathrm{MeOH}\left(7 \mathrm{~N} \mathrm{NH}_{3}\right) 90 / 10$ in $\left.10 \mathrm{CV}\right)$, then by flash chromatography on a reverse 
phase: C18 column $60 \mathrm{~g}$, from 100/0 A/B to 75/25 A/B, A: water/MeCN 95:5 + 0.1\% HCOOH B:MeCN/water 95:5 + 0.1\% HCOOH, to obtain the desired product (1-benzylpiperidin-4-yl)methyl 2-(3-(benzyloxy)phenyl)-2-hydroxy-2-phenylacetate (1d) $(715 \mathrm{mg}, 1.371 \mathrm{mmol}, 18.3 \%$ yield) as a white oil. ${ }^{1} \mathrm{H}$ NMR (600 MHz, DMSO-d6) $\delta$ ppm 7.20-7.42 (m, $\left.16 \mathrm{H}\right) 6.93-6.97(\mathrm{~m}, 2 \mathrm{H}) 6.90-6.93(\mathrm{~m}, 1 \mathrm{H})$ $6.60(\mathrm{~s}, 1 \mathrm{H}) 5.05(\mathrm{~s}, 2 \mathrm{H}) 3.99(\mathrm{~d}, \mathrm{~J}=6.44 \mathrm{~Hz}, 2 \mathrm{H}) 3.40(\mathrm{br} \mathrm{s}, 2 \mathrm{H}) 2.73(\mathrm{br} \mathrm{d}, \mathrm{J}=10.01 \mathrm{~Hz}, 2 \mathrm{H}) 1.76-1.92$ $(\mathrm{m}, 2 \mathrm{H}) 1.49-1.58(\mathrm{~m}, 1 \mathrm{H}) 1.47(\mathrm{br} \mathrm{d}, \mathrm{J}=12.92 \mathrm{~Hz}, 2 \mathrm{H}) 1.12(\mathrm{br} \mathrm{d}, \mathrm{J}=12.16 \mathrm{~Hz}, 2 \mathrm{H}) ;{ }^{13} \mathrm{C}$ NMR (151 MHz, DMSO-d6) $\delta$ ppm 173.40 (s, 1 C) 158.31 (s, 1 C) 145.33 (s, 1 C) 143.63 (s, 1 C) 137.46 (s, 1 C) 129.24 - 129.35 (m, 1 C) 129.16 (br s, 1 C) 128.85 (s, 1 C) 128.50-128.65 (m, 1 C) 128.23 - 128.31 (m, 1 C) $128.18(\mathrm{~s}, 1 \mathrm{C}) 128.04(\mathrm{~s}, 1 \mathrm{C})$ 127.85-127.94 (m, 1 C) 127.42-127.56 (m, 1 C) 127.17-127.35 (m, 1 C) 120.14 (s, 1 C) 114.63 (s, 1 C) 113.84 (s, 1 C) 81.11 (s, 1 C) 69.79 (s, 1 C) 69.68 (s, 1 C) 62.75 (s, 1 C) 53.04 (s, 1 C) 40.58 (s, 1 C) 35.38 (s, 1 C) 28.62 (s, 1 C). HRMS (ESI-TOF): Exact mass calculated for $\mathrm{C}_{34} \mathrm{H}_{35} \mathrm{NO}_{4}[\mathrm{M}]^{+}=521.2566$, Found $[\mathrm{M}+\mathrm{H}]^{+}=522.2642-$. To ${ }^{1} \mathrm{H}$ NMR and ${ }^{13} \mathrm{C}$ NMR spectra of $1 \mathrm{~d}$ are reported in Supplementary Materials (Figures S8 and S9, respectively).

4.6. Procedure for the Synthesis of methyl

2-(3-(3-(((benzyloxy)carbonyl)amino)propoxy)phenyl)-2-hydroxy-2-phenylacetate (1e)

Methyl 2-hydroxy-2-(3-hydroxyphenyl)-2-phenylacetate (2b) (570 mg, $2.207 \mathrm{mmol}$ ) and 3-(((benzyloxy)carbonyl)amino)propyl methanesulfonate $(761 \mathrm{mg}, 2.65 \mathrm{mmol})$ were dissolved in DMF $(6 \mathrm{~mL})$, followed by the addition of $\mathrm{CsCO}_{3}(1079 \mathrm{mg}, 3.31 \mathrm{mmol})$. The reaction solution was stirred at room temperature overnight. The reaction mixture was quenched adding water then extracted with EtOAc. The organic phase was dried over $\mathrm{Na}_{2} \mathrm{SO}_{4}$, filtered and evaporated under reduced pressure. The crude was purified by flash chromatography (25 g silica, from 20 to $50 \%$ EtOAc in heptane) to obtain the desired product methyl 2-(3-(3-(((benzyloxy)carbonyl)amino)propoxy)phenyl)-2-hydroxy-2-phenylacetate (1e) (670 mg, $1.491 \mathrm{mmol}, 67.5 \%$ yield) as a colourless oil. ${ }^{1} \mathrm{H}$ NMR (600 MHz, DMSO-d6) $\delta$ ppm 7.27-7.39 $(\mathrm{m}, 11 \mathrm{H}) 7.24(\mathrm{t}, \mathrm{J}=8.27 \mathrm{~Hz}, 1 \mathrm{H}) 6.88-6.92(\mathrm{~m}, 2 \mathrm{H}) 6.82-6.88(\mathrm{~m}, 1 \mathrm{H}) 6.67(\mathrm{~s}, 1 \mathrm{H}) 5.02(\mathrm{~s}, 2 \mathrm{H}) 3.94(\mathrm{t}$, $\mathrm{J}=6.28 \mathrm{~Hz}, 2 \mathrm{H}) 3.72(\mathrm{~s}, 3 \mathrm{H}) 3.16(\mathrm{q}, \mathrm{J}=6.54 \mathrm{~Hz}, 2 \mathrm{H}) 1.85$ (quin, J = 6.51 Hz, $2 \mathrm{H}) ;{ }^{13} \mathrm{C} \mathrm{NMR}(151 \mathrm{MHz}$, DMSO-d6) $\delta$ ppm 173.97 (s, 1 C) 158.36 (s, 1 C) 145.33 (s, 1 C) 143.63 (s, 1 C) 137.45 (s, 1 C) 129.35 (s, $1 \mathrm{C}) 128.88(\mathrm{~s}, 1 \mathrm{C}) 128.28(\mathrm{~s}, 1 \mathrm{C}) 128.25(\mathrm{~s}, 1 \mathrm{C}) 128.15(\mathrm{~s}, 1 \mathrm{C}) 127.92(\mathrm{~s}, 1 \mathrm{C}) 127.40(\mathrm{~s}, 1 \mathrm{C}) 120.06(\mathrm{~s}$, 1 C) 114.50 (s, 1 C) 113.84 (s, 1 C) 81.05 (s, 1 C) 69.70 (s, 1 C) 52.96 (s, 1 C). HRMS (ESI-TOF): Exact mass calculated for $\mathrm{C}_{26} \mathrm{H}_{27} \mathrm{NO}_{6}[\mathrm{M}-\mathrm{H}]^{-}=448.1766$, Found: $[\mathrm{M}+\mathrm{NH} 4]^{+}=467.2177 .{ }^{1} \mathrm{H}$ NMR and ${ }^{13} \mathrm{C} \mathrm{NMR}$ spectra of 1a are reported in Supplementary Materials (Figures S10 and S11, respectively).

\subsection{Enantiomeric Excess Determination}

The enantiomeric excess (ee \%) was determined by HPLC with a Kromasil 5-Amycoat column $4.6 \times 250 \mathrm{~mm}, 5 \mu \mathrm{m}$, mobile phase: $n$-hexane:isopropanol:TFA 8:2:0.1\%, flow rate $1 \mathrm{~mL} / \mathrm{min}$, $\lambda=220 \mathrm{~nm}$. Retention times: (R)-1a $10.1 \mathrm{~min}$; (S)-1a: $11.5 \mathrm{~min}$; $(R)-2 \mathrm{a} 20.7 \mathrm{~min}$; $(S)-2 \mathrm{a}: 34.6 \mathrm{~min}$; (S)-1b: $11.3 \mathrm{~min}$; (R)-1b: $11.5 \mathrm{~min}$; (S)-2b: $14.1 \mathrm{~min}$; $(R)-2 \mathrm{~b}: 16.1 \mathrm{~min}$; $(R)-1 \mathrm{e}: 16.3 \mathrm{~min}$; $(S)-1 \mathrm{e}:$ $17.4 \mathrm{~min}$; $(R)$-2e: $23.8 \mathrm{~min}$; $(S)-2 \mathrm{e} 29.1 \mathrm{~min}$. Representative HPLC chromatograms are reported in Supplementary Materials (Figure S18).

\subsection{General Procedure for Biotransformations}

Screening and optimization were carried out by performing reactions in $5 \mathrm{~mL}$ screw-capped test tubes with a reaction volume of $2 \mathrm{~mL}$. Preparative biotransformations were carried out at 25 and $150 \mathrm{~mL}$ scale. Substrates $(2.5-10 \mathrm{mM}$ ) were dissolved in DMSO (final concentration $5 \%$ ) and added to phosphate buffer $(100 \mathrm{mM}, \mathrm{pH}=7)$. The reactions were started by the addition of the enzyme. The mixture was then kept at fixed temperature under magnetic stirring. Samples of the biotransformation mixture were withdrawn, diluted with an equal volume of water, acidified with $1 \mathrm{~N} \mathrm{HCl}$ and extracted with eight volumes of EtOAc. The organic extract was then concentrated and analysed by HPLC. 
4.8.1. (S)-2-(3-(Benzyloxy)phenyl)-2-hydroxy-2-phenylacetic acid (2a)

${ }^{1} \mathrm{H}$ NMR (600 MHz, DMSO-d6) $\delta$ ppm 12.20-13.89 (m, $\left.1 \mathrm{H}\right) 9.31(\mathrm{~s}, 1 \mathrm{H}) 7.36-7.39$ (m, $\left.2 \mathrm{H}\right)$ 7.29-7.34 (m, 2 H) 7.24-7.29 (m, 1 H) 7.11 (t, J = 7.89 Hz, 1 H) $6.82(\mathrm{br} \mathrm{s}, 1 \mathrm{H}) 6.79-6.82(\mathrm{~m}, 1 \mathrm{H}) 6.66$ $(\mathrm{ddd}, \mathrm{J}=8.05,2.34,1.03 \mathrm{~Hz}, 1 \mathrm{H}) 5.48-6.50(\mathrm{~m}, 1 \mathrm{H}){ }^{13} \mathrm{C}$ NMR $(151 \mathrm{MHz}, \mathrm{DMSO}-\mathrm{d} 6) \delta \mathrm{ppm} 175.14(\mathrm{~s}$, 1 C) $157.22(\mathrm{~s}, 1 \mathrm{C}) 145.55(\mathrm{~s}, 1 \mathrm{C}) 144.17(\mathrm{~s}, 1 \mathrm{C}) 129.00(\mathrm{~s}, 1 \mathrm{C}) 128.01(\mathrm{~s}, 1 \mathrm{C}) 127.59(\mathrm{~s}, 1 \mathrm{C}) 118.21(\mathrm{~s}$, 1 C) $114.86(\mathrm{~s}, 1 \mathrm{C}) 114.66(\mathrm{~s}, 1 \mathrm{C}) 80.63(\mathrm{~s}, 1 \mathrm{C})$. HRMS (ESI-TOF): Exact mass calculated for $\mathrm{C}_{14} \mathrm{H}_{12} \mathrm{O}_{4}$ $[\mathrm{M}-\mathrm{H}]^{-}=243.0663$; Found: $[\mathrm{M}+\mathrm{Na}]^{+}=267.0626$.

\subsection{2. (S)-2-Hydroxy-2-(3-hydroxyphenyl)-2-phenylacetic acid (2b)}

${ }^{1} \mathrm{H}$ NMR (600 MHz, DMSO-d6) $\delta$ ppm 13.21 (br s, $\left.1 \mathrm{H}\right)$ 7.41-7.45 (m, $\left.2 \mathrm{H}\right)$ 7.36-7.41 (m, $\left.4 \mathrm{H}\right)$ 7.23-7.35 (m, 5 H) 7.01-7.05 (m, 1 H) 6.93-7.00 (m, 2 H) $6.34(\mathrm{~s}, 1 \mathrm{H}) 5.05(\mathrm{~s}, 2 \mathrm{H}) ;{ }^{13} \mathrm{C} \mathrm{NMR}(151 \mathrm{MHz}$, DMSO-d6) $\delta$ ppm 175.01 (s, 1 C) 158.31 (s, 1 C) 145.68 (s, 1 C) 143.96 (s, 1 C) 137.47 (s, 1 C) 129.20 (s, $1 \mathrm{C}) 128.88(\mathrm{~s}, 1 \mathrm{C}) 128.28(\mathrm{~s}, 1 \mathrm{C}) 128.18(\mathrm{~s}, 1 \mathrm{C}) 128.13(\mathrm{~s}, 1 \mathrm{C}) 127.71(\mathrm{~s}, 1 \mathrm{C}) 127.50(\mathrm{~s}, 1 \mathrm{C}) 120.23(\mathrm{~s}$, 1 C) $114.72(\mathrm{~s}, 1 \mathrm{C}) 113.50(\mathrm{~s}, 1 \mathrm{C}) 80.61$ (s, 1 C) 69.70 (s, 1C). HRMS (ESI-TOF): Exact mass calculated for $\mathrm{C}_{21} \mathrm{H}_{18} \mathrm{O}_{4}[\mathrm{M}-\mathrm{H}]^{+}=333.1132$, Found: $\left[\mathrm{M}+\mathrm{NH}_{4}\right]^{-}=352.1541$.

4.8.3. (S)-2-(3-(3-(((Benzyloxy)carbonyl)amino)propoxy)phenyl)-2-hydroxy-2-phenylacetic acid (2e)

${ }^{1} \mathrm{H}$ NMR (600 MHz, DMSO-d6) $\delta$ ppm 13.15 (br s, $\left.1 \mathrm{H}\right)$ 7.29-7.41 (m, $\left.10 \mathrm{H}\right) 7.25-7.29(\mathrm{~m}, 1 \mathrm{H})$ 7.21-7.24 (m, $1 \mathrm{H}) 6.92-6.97(\mathrm{~m}, 2 \mathrm{H}) 6.77-6.89(\mathrm{~m}, 1 \mathrm{H}) 6.31(\mathrm{br} \mathrm{s}, 1 \mathrm{H}) 5.01(\mathrm{~s}, 2 \mathrm{H}) 3.93(\mathrm{t}, \mathrm{J}=6.22 \mathrm{~Hz}$, $2 \mathrm{H}) 3.15$ (q, J = $6.63 \mathrm{~Hz}, 2 \mathrm{H}) 1.84$ (quin, J = 6.51 Hz, $2 \mathrm{H}$ ); ${ }^{13} \mathrm{C}$ NMR (151 MHz, DMSO-d6) $\delta \mathrm{ppm}$ 174.98 (s, 1 C) $158.50(\mathrm{~s}, 1 \mathrm{C}) 156.61(\mathrm{~s}, 1 \mathrm{C}) 145.71(\mathrm{~s}, 1 \mathrm{C}) 144.13(\mathrm{~s}, 1 \mathrm{C}) 137.71$ (s, 1 C) 129.05-129.19 $(\mathrm{m}, 1 \mathrm{C}) 128.81(\mathrm{~s}, 1 \mathrm{C}) 128.15-128.36(\mathrm{~m}, 1 \mathrm{C}) 128.08(\mathrm{~s}, 1 \mathrm{C}) 127.60-127.69(\mathrm{~m}, 1 \mathrm{C}) 127.47-127.58(\mathrm{~m}$, 1 C) $119.97(\mathrm{~s}, 1 \mathrm{C}) 114.29(\mathrm{~s}, 1 \mathrm{C})$ 112.27-113.50 (m, 1 C) 80.59 (s, 1 C) 65.85 (s, 1 C) 65.12-65.56 (m, 1 C) $37.45-38.24(\mathrm{~m}, 1 \mathrm{C}) 29.64(\mathrm{~s}, 1 \mathrm{C})$. HRMS (ESI-TOF): Exact mass calculated for $\mathrm{C}_{26} \mathrm{H}_{27} \mathrm{NO}_{6}[\mathrm{M}]^{+}=$ 435.1682, Found $[\mathrm{M}+\mathrm{H}]^{+}=436.1754 ;[\alpha]_{\mathrm{D}}=-3.4\left(\mathrm{CHCl}_{3} ; \mathrm{c}=1\right)$.

4.9. Procedure for the Synthesis of methyl

(S)-2-(3-(3-(((benzyloxy)carbonyl)amino)propoxy) phenyl)-2-hydroxy-2-phenylacetate (optically enriched 1e)

(S)-2-(3-(3-(((Benzyloxy)carbonyl)amino)propoxy)phenyl)-2-hydroxy-2-phenylacetic acid (100 mg, $0,23 \mathrm{mmol})$ obtained by biotranformation was dissolved in $\mathrm{MeOH}(1,5 \mathrm{~mL})$ and slowly added $\mathrm{SOCl}_{2}$ $(0,5 \mathrm{~mL})$ at $0{ }^{\circ} \mathrm{C}$. The reaction mixture was refluxed at $70{ }^{\circ} \mathrm{C}$ for $2 \mathrm{~h}$, after which time it was cooled to RT. $\mathrm{MeOH}$ was removed in vacuum and the resulting residue was poured onto ice- $\mathrm{H}_{2} \mathrm{O}$ and extracted with EtOAc. The combined organic extracts were washed with $10 \% \mathrm{NaHCO}_{3}$, brine, dried over $\mathrm{Na}_{2} \mathrm{SO}_{4}$, and evaporated to provide the product as a white solid (101 mg, 98\% yield). ${ }^{1} \mathrm{H}$ NMR $(600 \mathrm{MHz}$, DMSO-d6) $\delta$ ppm 7.20-7.40 (m, 12 H) 6.84-6.86 (m, 1 H) 6.82-6.90 (m, 2 H) $6.65(\mathrm{~s}, 1 \mathrm{H}) 5.01(\mathrm{~s}, 2 \mathrm{H})$ $3.93(\mathrm{t}, \mathrm{J}=6.22 \mathrm{~Hz}, 2 \mathrm{H}) 3.72(\mathrm{~s}, 3 \mathrm{H}) 3.15(\mathrm{q}, \mathrm{J}=6.67 \mathrm{~Hz}, 2 \mathrm{H}) 1.84$ (quin, $\mathrm{J}=6.54 \mathrm{~Hz}, 2 \mathrm{H}) ;{ }^{13} \mathrm{C} \mathrm{NMR}$ (151 MHz, DMSO-d6) $\delta$ ppm 172.50-174.93 (m, 1 C) 158.11-159.19 (m, 1 C) 155.83-157.71 (m, 1 C) 144.39-146.14 (m, 1 C) 143.20-144.08 (m, 1 C) 137.30-137.95 (m, 1 C) 129.20-129.50 (m, 1 C) 128.80 (br d, $\mathrm{J}=27.51 \mathrm{~Hz}, 1 \mathrm{C}) 128.24(\mathrm{~s}, 1 \mathrm{C}) 128.20(\mathrm{br} \mathrm{d}, \mathrm{J}=3.30 \mathrm{~Hz}, 1 \mathrm{C}) 127.82-127.98(\mathrm{~m}, 1 \mathrm{C}) 127.29-127.52(\mathrm{~m}$, 1 C) 119.48-120.06 (m, 1 C) 113.96-114.24 (m, 1 C) $113.42(\mathrm{~s}, 1 \mathrm{C}) 81.06(\mathrm{~s}, 1 \mathrm{C}) 65.65(\mathrm{~s}, 1 \mathrm{C}) 65.51(\mathrm{~s}, 1 \mathrm{C})$ 52.40 - 53.57 (m, 1 C) 37.02 - 38.35 (m, 1 C) 28.67-29.99 (m, 1 C); HRMS (ESI-TOF): Exact mass calculated for $\mathrm{C}_{26} \mathrm{H}_{27} \mathrm{NO}_{6}[\mathrm{M}-\mathrm{H}]^{-}=448.1766$, Found: $[\mathrm{M}+\mathrm{H}]^{+}=450.1913 .{ }^{1} \mathrm{H}$ NMR and ${ }^{13} \mathrm{C}$ NMR spectra of optically enriched 1e are reported in Supplementary Materials (Figures S12 and S13, respectively).

Supplementary Materials: The following are available online at http:/ /www.mdpi.com/2073-4344/9/2/113/s1, Table S1: Control variables and initial levels considered for the optimization. Figure S1: Sequential optimization of the PLE-catalysed hydrolysis of 1e. Figure S2: ${ }^{1} \mathrm{H}$ NMR spectrum of 1a. Figure S3: ${ }^{13} \mathrm{C}$ NMR spectrum of $1 \mathrm{a}$. Figure S4: ${ }^{1} \mathrm{H}$ NMR spectrum of 1b. Figure S5: ${ }^{13} \mathrm{C}$ NMR spectrum of 1b. Figure S6: ${ }^{1} \mathrm{H}$ NMR spectrum of $1 \mathrm{c}$. Figure S7: ${ }^{13} \mathrm{C}$ NMR spectrum of 1c. Figure S8: ${ }^{1} \mathrm{H}$ NMR spectrum of $1 \mathrm{~d}$. Figure S9: ${ }^{13} \mathrm{C}$ NMR spectrum of $1 \mathrm{~d}$. Figure S10: ${ }^{1} \mathrm{H}$ NMR spectrum of 1e. Figure S11: ${ }^{13} \mathrm{C}$ NMR spectrum of 1e. Figure S12: ${ }^{1} \mathrm{H}$ NMR spectrum of (S)-2a. Figure S13. ${ }^{13} \mathrm{C}$ NMR spectrum of (S)-2a. Figure S14: ${ }^{1} \mathrm{H}$ NMR spectrum of (S)-2b. Figure S15. ${ }^{13} \mathrm{C}$ NMR 
spectrum of (S)-2b. Figure S16: ${ }^{1} \mathrm{H}$ NMR spectrum of $(S)$-2e. Figure S17. ${ }^{13} \mathrm{C}$ NMR spectrum of $(S)-2 e$. Figure S18: Chiral HPLC of the hydrolysis of $1 \mathrm{e}$ to $2 \mathrm{e}$ catalysed by PLE.

Author Contributions: Conceptualization, A.P., F.M., D.R. and F.R.; methodology, I.S., M.L.C. and L.C.; software, D.R. and I.S.; validation, A.P., R.M. and L.C.; formal analysis, R.M., M.L.C. and A.P.; investigation, D.R., I.S., R.M. and M.L.C.; resources, F.M. and F.R.; data curation, F.M., A.P., F.R., R.M., L.C. and I.S.; writing-original draft preparation, A.P. and F.M.; writing—review and editing, all the authors; supervision, F.M., D.R., A.P. and F.R.; project administration, A.P., F.M., F.R. and L.C. All authors discussed the results and commented on the manuscript.

Funding: This research received no external funding.

Conflicts of Interest: The authors declare no conflict of interest.

\section{References}

1. Bornscheuer, U.T.; Kazlauskas, R.T. Hydrolases in Organic Synthesis; Wiley-VCH: Weinheim, Germany, 1999.

2. Gotor-Fernandez, V.; Brieva, R.; Gotor, V. Lipases: Useful biocatalysts for the preparation of pharmaceuticals. J. Mol. Catal. B. 2006, 40, 111-120. [CrossRef]

3. De Miranda, A.S.; Miranda, L.S.M.; de Souza, R.O.M.A. Lipases: Valuable catalysts for dynamic kinetic resolutions. Biotechnol. Adv. 2015, 33, 372-393. [CrossRef] [PubMed]

4. Romano, D.; Bonomi, F.; de Mattos, M.C.; de Sousa Fonseca, T.; de Oliveira, M.C.F.; Molinari, F. Esterases as stereoselective biocatalysts. Biotechnol. Adv. 2015, 33, 547-565. [CrossRef] [PubMed]

5. Carvalho, A.C.; de Sousa Fonseca, T.; de Mattos, M.C.; de Oliveira, M.C.F.; de Lemos, T.L.; Molinari, F.; Romano, D.; Serra, I. Recent advances in lipase-mediated preparation of pharmaceuticals and their intermediates. Int. J. Mol. Sci. 2015, 16, 29682-29716. [CrossRef] [PubMed]

6. Bornscheuer, U.T. Methods to increase enantioselectivity of lipases and esterases. Curr. Opin. Biotechnol. 2002, 13, 543-547. [CrossRef]

7. Juhl, P.B.; Doderer, K.; Hollmann, F.; Thum, O.; Pleiss, J. Engineering of Candida antarctica lipase B for hydrolysis of bulky carboxylic acid esters. J. Biotechnol. 2010, 150, 474-480. [CrossRef] [PubMed]

8. Pogorevc, M.; Faber, K. Biocatalytic resolution of sterically hindered alcohols, carboxylic acids and esters containing fully substituted chiral centers by hydrolytic enzymes. J. Mol. Catal. B. 2000, 10, 357-376. [CrossRef]

9. Kourist, R.; Bornscheuer, U.T. Biocatalytic synthesis of optically active tertiary alcohols. Appl. Microbiol. Biotechnol. 2011, 91, 505-517. [CrossRef] [PubMed]

10. Rodríguez-Rodríguez, J.A.; Gotor, V.; Brieva, R. Lipase catalyzed resolution of the quaternary stereogenic center in ketone-derived benzo-fused cyclic cyanohydrins. Tetrahedron: Asymmetry 2011, 22, 1218-1224. [CrossRef]

11. Lalonde, J.J.; Bergbreiter, D.E.; Wong, C.-H. Enzymatic kinetic resolution of $\alpha$-nitro $\alpha$-methyl carboxylic acids. J. Org. Chem. 1988, 53, 2323-2327. [CrossRef]

12. Kometani, T.; Isobe, T.; Goto, M.; Takeuchi, Y.; Haufe, G. Enzymatic resolution of 2-fluoro-2-arylacetic acid derivatives. J. Mol. Catal. B 1988, 5, 171-174. [CrossRef]

13. Miyazawa, T.; Shimaoka, M.; Yamada, T. Resolution of 2-cyano-2-methylalkanoic acids via porcine pancreatic lipase-catalyzed enantioselective ester hydrolysis: effect of the alcohol moiety of the substrate ester on enantioselectivity. Biotechnol. Lett. 1999, 21, 309-312. [CrossRef]

14. Domínguez de María, P.; García-Burgos, C.A.; Bargeman, G.; van Gemert, R.W. Pig Liver Esterase (PLE) as biocatalyst in organic synthesis: from nature to cloning and to practical applications. Synthesis 2007, 10, 1439-1452. [CrossRef]

15. Namiki, Y.; Fujii, T.; Nakada, M. Preparation of chiral building blocks for the enantioselective total synthesis of ent-kauranoids by the pig liver esterase-catalyzed asymmetric hydrolysis of a dialkyl malonate-type prochiral diester. Tetrahedron: Asymmetry 2014, 25, 718-724. [CrossRef]

16. Rancati, F.; Rizzi, A.; Carzaniga, L.; Linney, I.; Knight, C.; Schmidt, W. Compounds having muscarinic receptor antagonist and beta2 adrenergic receptor agonist activity. Patent WO 2016/128456 Al, August 2016.

17. Rancati, F.; Rizzi, A.; Carzaniga, L.; Linney, I.; Knight, C.; Schmidt, W. Compounds having muscarinic receptor antagonist and beta2 adrenergic receptor agonist activity. Patent WO 2018/011090 A1, January 2018.

18. Montuschi, Z.; Macagno, F.; Valente, S.; Fuso, L. Inhaled muscarinic acetylcholine receptor antagonists for treatment of COPD. Curr Med Chem. 2013, 20, 1464-1476. [CrossRef] [PubMed] 
19. Gandolfi, R.; Marinelli, F.; Lazzarini, A.; Molinari, F. Cell-bound and extracellular carboxylesterases from Streptomyces: hydrolytic and synthetic activities. J. Appl Microbiol 2000, 89, 870-875. [CrossRef] [PubMed]

20. Converti, A.; Del Borghi, A.; Gandolfi, R.; Lodi, A.; Molinari, F.; Palazzi, E. Simplified kinetics and thermodynamics of geraniol acetylation by lyophilized cells of Aspergillus oryzae. Biotechnol. Bioeng. 2002, 77, 232-237. [CrossRef]

21. Molinari, F.; Romano, D.; Gandolfi, R.; Kroppenstedt, R.M.; Marinelli, F. Newly isolated Streptomyces spp. as enantioselective biocatalysts: hydrolysis of 1,2-O-isopropylidene glycerol racemic esters. J. Appl. Microbiol. 2005, 99, 960-967. [CrossRef]

22. Molinari, F.; Cavenago, K.S.; Romano, A.; Romano, D.; Gandolfi, R. Enantioselective hydrolysis of (RS)-isopropylideneglycerol acetate with Kluyveromyces marxianus. Tetrahedron: Asymmetry 2004, 15, 1945-1947. [CrossRef]

23. Monti, D.; Ferrandi, E.E.; Righi, M.; Romano, D.; Molinari, F. Purification and characterization of the enantioselective esterase from Kluyveromyces marxianus CBS 1553. J. Biotechnol. 2008, 133, 65-72. [CrossRef]

24. De Vitis, V.; Nakhnoukh, C.; Pinto, A.; Contente, M.L.; Barbiroli, A.; Milani, M.; Bolognesi, M.; Molinari, F.; Gourlay, L.; Romano, D. A stereospecific carboxyl esterase from Bacillus coagulans hosting nonlipase activity within a lipase-like fold. FEBS J. 2018, 285, 903-914. [CrossRef] [PubMed]

25. Hummel, A.; Brüsehaber, E.; Böttcher, D.; Trauthwein, H.; Doderer, K.; Bornscheuer, U.T. Isoenzymes of Pig-Liver Esterase reveal striking differences in enantioselectivities. Angew. Chem. Int. Ed. Engl. 2007, 46, 8492-8494. [CrossRef] [PubMed]

26. Romano, D.; Gandolfi, R.; Guglielmetti, S.; Molinari, F. Enzymatic hydrolysis of capsaicins for the production of vanillylamine using ECB deacylase from Actinoplanes utahensis. Food Chem. 2011, 124, 1096-1098. [CrossRef]

27. Bjorkling, F.; Boutelje, J.; Gatenbeck, S.; Hult, K.; Norin, T. Enzyme catalysed hydrolysis of dialkylated propanedioic acid diesters, chain length dependent reversal of enantioselectivity. Appl. Microbiol. Biotechnol. 1985, 21, 16-19. [CrossRef]

28. Del Valle, E.M.M. Cyclodextrins and their uses: a review. Process Biochem. 2004, 39, 1033-1046. [CrossRef]

(C) 2019 by the authors. Licensee MDPI, Basel, Switzerland. This article is an open access article distributed under the terms and conditions of the Creative Commons Attribution (CC BY) license (http://creativecommons.org/licenses/by/4.0/). 